\title{
Inventory in situ of plant resources used as fuel in the Semiarid Region of Northeast Brazil
}

\author{
Gleicy Deise Santos Lima, José Ribamar de Farias Lima, Núbia da \\ Silva, Rodrigo Silva de Oliveira and Reinaldo Farias Paiva Lucena*
}

Universidade Federal da Paraíba. Centro de Ciências Agrárias. Departamento de Fitotecnia e Ciências Ambientais. Laboratório de Etnoecologia. Areia-PB. Brazil (CEP 58397-000).*Email: rfplnal@gmail.com.

\begin{abstract}
Timber resources are constantly used by traditional communities to meet their everyday needs. Assuming the importance and use of these resources for energy purposes, we applied the inventory in situ method, over 12 months, aiming to identify the species most used as firewood and charcoal, their dynamics of renewal, and species availability in the forest fragment studied. The study was conducted in the Rural Community of São Francisco, Municipality of Cabaceiras (Paraíba State, Northeast Brazil). Overall, we recorded 15 species, 14 genera, and 6 botanical families, from which Fabaceae (8 spp) and Anacardiaceae (3 spp) were the most prominent, due to having greater diversity of species. The most used native species in the community was Myracrodruon urundeuva Allemão (aroeira) and we also recorded the constant use of Prosopis juliflora (algaroba), which is an exotic species. The results evidenced the effective use of natural resources, and may complement in general ethnobotanical studies.
\end{abstract}

Keywords: Caatinga; Ethnobotany; Traditional Populations.
Received

December 30, 2015

Accepted

April 11, 2016

Released

June 30, 2016

Open Acess Full Text Article

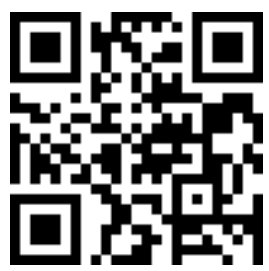

\footnotetext{
ORCIID

D. 0000-0003-4326-5693 Gleicy Deise Santos Lima

(2) 0000-0001-5705-0672 José Ribamar de Farias Lima

C 0000-0001-8558-8250 Núbia da Silva

(2) 0000-0002-7322-932X Rodrigo Silva de Oliveira

(c) 0000-0003-4775-7775

Reinaldo Farias Paiva

Lucena
}

\section{Introduction}

The Caatinga is marked, historically, by its seasonality, and pressure on its species, due to the removing of timber resources, mainly for energy purposes, leading to the wrong characterization of this area as poor in endemism, animal and plant diversity (Severo, 2009). This distorted view has 
lbeen modified by studies that show the Caatinga as rich in biodiversity (Oliveira et al., 2003; Leal et al., 2005). The vegetation is known for its use as timber and nontimber resource, with great importance for the people who live in the region (Albuquerque and Andrade, 2002). Thus, several studies have been performed over the years, in various fields of science, such as ethnobiology, which seeks to record and evaluate the empirical knowledge concerning natural resources (Ford, 1978; Posey and Overal, 1990; Berlin, 1992; Balick and Cox, 1996; Diegues and Arruda, 2001).

Within this complex area of knowledge, ethnobotany rescues and values the traditional knowledge of local communities in order to understand the use of plant resources and their management day-to-day. Ethnobotany has become a tool that enables the identification of the species most commonly used by people, and revealing their great importance to those who use them, as well as providing important information for the management and conservation of local plant diversity (Luoga et al., 2000; La Torre-Cuadros and Islebe, 2003; Shanley and Rosa, 2004; Albuquerque et al., 2005; Ferraz et al., 2005, 2006; Hanazaki et al., 2006; ReyesGarcía et al., 2005; Ramos et al., 2008a, 2008b). In this context, studies concerning the use of wood species from Caatinga can be the basis for understanding the dynamics of extraction of these plants (Medeiros et al., 2011), providing information that may contribute to conservation actions, investigating social and economic aspects of local communities, and ensuring the perpetuation of knowledge and sustainable use of plant resources (Albuquerque and Andrade, 2002b).

In order to understand these uses, ethnobotanical inventories are tools relevant for obtaining knowledge about the extraction of plant resources. According to Martins et al. (2006), the inventory is not a methodology that aims to generate a complete list of species for the studied areas, but rather provide primordial data concerning their diversity, so data are quickly available. The inventory in situ is a tool that identifies the resources from the plants currently used (Gaugris and Van Rooyen, 2006), based on the premise that if the product is inside a residence, this means it is effectively used (Lucena et al., 2013). Studies that employ such a method present different definitions (Kvist et al., 2001; Stagegaard et al., 2002; Gavin and Anderson, 2005) and several ways of applying it; this lack of standardization can hamper the discussions of recorded information.

Although some researchers do not emphasize the use of this method, we can distinguish its application and principles in ethnobotanical studies of agroforest gardens (Albuquerque et al., 2005b; Florentino et al., 2007) and those conducted with specific categories, such as fuel, that require home visits and observations (Ramos et al., 2008; Sá et al., 2009). This is because biofuels are the main source of energy in rural areas in developing countries, due to the traditional use of wood, as well as socioeconomic factors. Thus, the collection of firewood increases, making deforestation and possible local extinctions relevant problems.

This approach was developed in a study conducted in Kenya by DahdouhGuebas et al. (2006), in which, according to the frequency of species in the inventory in situ, it was possible to classify the most important species. However, it is necessary to provide a detailed description of the use and extraction dynamic of plant resources, since their frequency of collection, the species ecology, and amount of collected material influence the results, which may indicate species that suffer greater extraction (Lucena et al., 2013).

The results obtained in our study can corroborate other research already conducted in the Caatinga, providing information that may assist in the development of conservation programs for native species, and in the identification of species used as fuel, as well as indicate species that deserve greater attention regarding conservation.

Given the above, this study aimed to record and monitor the diversity of timber plant resources for energy purposes, 
which are used by the population of São Francisco, municipality of Cabaceiras, in the semiarid region of Paraíba, northeast Brazil, and to list the species recorded as useful for firewood and charcoal, observing the renewal standard of these resources, and verifying the availability of native species in the forest fragment studied.

\section{Materials and methods}

\section{The regional context}

The study was conducted in Rural Community of São Francisco, Municipality of Cabaceiras, Paraíba State, Northeast Brazil (Figure 1). It has an area of 452.920 $\mathrm{km}^{2}$ in the Borborema Mesoregion and the Cariri Oriental Microregion, at the geographic coordinates of $7^{\circ} 21^{\prime} 32.68^{\prime \prime}$ and $7^{\circ} 36^{\prime} 04.86^{\prime}$ " S latitude and $36^{\circ} 11^{\prime} 36.54^{\prime \prime}$ and $3^{\circ} 26^{\prime} 17.48^{\prime \prime} \mathrm{W}$ longitude. It borders the Municipalities of Campina Grande (North), Barra de São Miguel and São Domingos do Cariri (South), Boqueirão (East), and São João do Cariri (West). The total population is 5,035 inhabitants $(2,217$ in the urban area and 2,818 in the rural area) (IBGE, 2011).

Rural Community of São Francisco is at an average altitude of approximately $500 \mathrm{~m}$. The climate is hot semiarid Bsh, according to the Köppen classification, with annual average temperatures of around $24.5^{\circ} \mathrm{C}$. The municipality has the lowest rainfall in Brazil, an average of $250 \mathrm{~mm}$ per year (Alves et al., 2008). The rains are irregular, occurring only during three months, before the drought begins and lasts up to 10 months in drier periods (IBGE, 2011).

\section{Study area}

Rural Community of São Francisco is divided into five locations: Caruatá de Dentro, Alto Fechado, Jerimum, Rio Direito, and Malhada Comprida. In Malhada Comprida there is a soccer field and an elementary school, named "Escola Municipal de Ensino Fundamental Malhada
Comprida". In Caruatá de Dentro there is a Catholic Church, a room that functions as a health center, providing care biweekly to local communities, and two farmers' associations.

Most residences have cisterns for collecting and storing water, given that drought periods are long. The community is approximately $14 \mathrm{~km}$ from downtown Cabaceiras. Most children and young people go to the municipality, to study, on a bus provided by the town council.

The main activities in the community are goat and sheep breeding, and corn and bean culture. The men of this community are predominantly involved in non-commercial subsistence farming. Most women work in the home and some provide auxiliary services in local schools.

The vegetation is predominantly composed of shrubby-arboreal species, native species such as the juazeiro (Ziziphus joazeiro Mart), aroeira (Myracrodruon urundeuva Allemão), and catingueira (Poincianela pyramidalis Tul), among others. There is also a predominance of Cactaceae such as the mandacaru (Cereus jamacaru DC) and coroa-de-frade (Melocactus bahiensis (Britton \& Rose) Luetzelb).

According to Silva (2012), the region is crossed by several rivers and streams, all of them with intermittent character. The Taperoá is the main river, and receives water from the rivers of Serra Branca, Gurjão, Soledade, and Riacho do Farias. All these affluents are part of the Médio Paraíba Basin, the waters of which converge with the Epitácio Pessoa Reservoir, located in the Municipality of Boqueirão.

The community borders the "Fazenda Pai Mateus", which is a Private Reserve of the Natural Heritage (PRNH), where the Brazilian Institute of Environment and Renewable Natural Resources (IBAMA) performs the release of wild animals captured in nearby towns. 

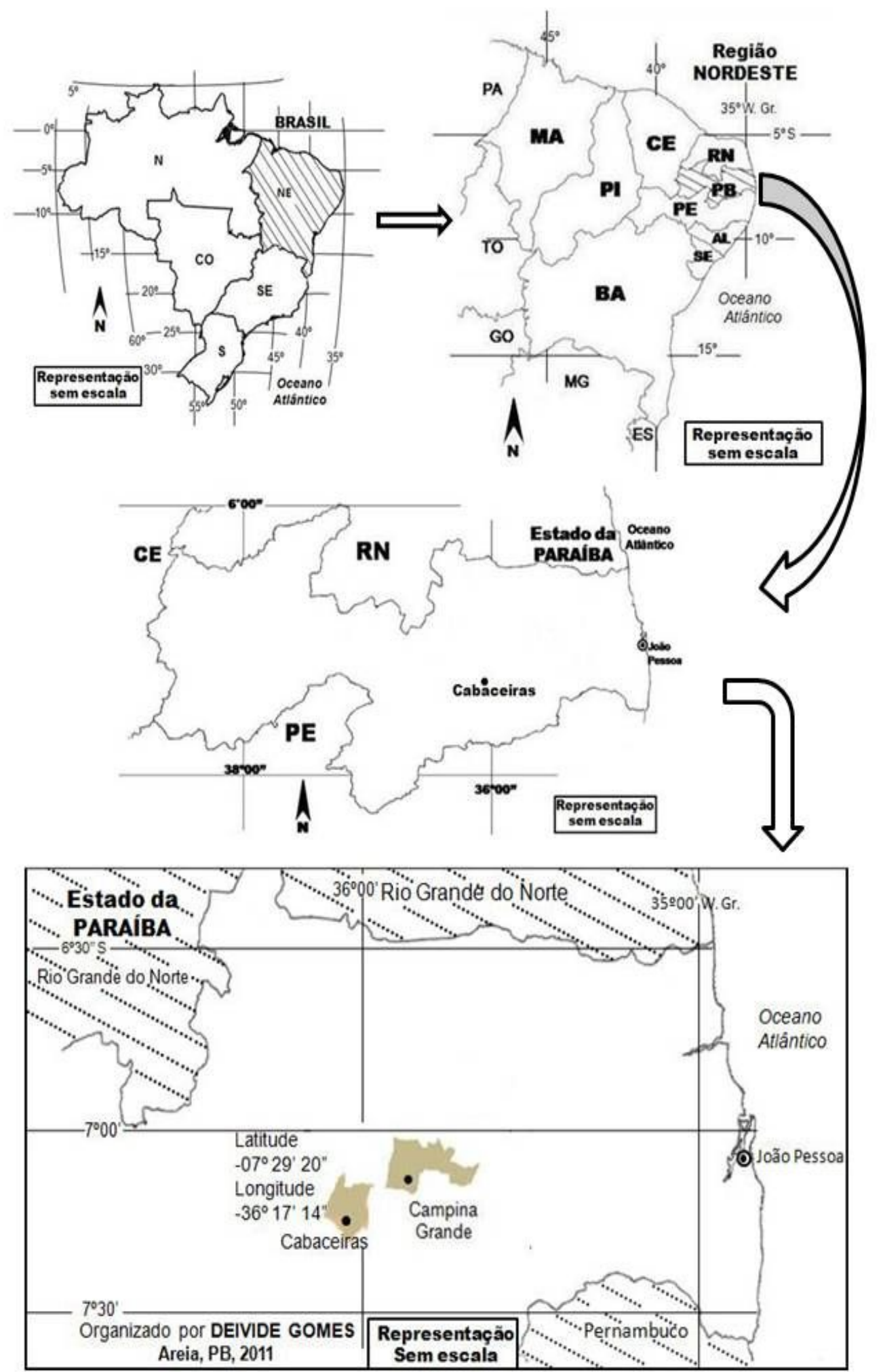

Figure 1. Location of Cabaceiras City, State of Paraíba, Northeastern Brazil. 


\section{Vegetation inventory}

To identify the species found in the region and their availability for energy use, we carried out vegetation samples in an area near the community of São Francisco, in order to collect phytosociological and botanical information. Thus, 90 contiguous plots were delimited, measuring $10 \times 10 \mathrm{~m}$ each, totaling 0.9 ha. We recorded all woody species with a stem diameter $\geq 3 \mathrm{~cm}$ at ground level (DGL), excluding cacti, bromeliads, vines, lianas, and small herbaceous (Araújo and Ferraz, 2010). We also recorded the height of each plant.

The phytosociological indices we used - basal area, importance value, relative density, relative dominance, and relative frequency - analyzed according to Araújo and Ferraz (2010), in which the Relative Density (RD, \%) was estimated by the number of individuals from a given taxon, related to the total number of individuals sampled. The Relative Frequency (RF, \%) was estimated based on TFS (total frequency of the species in question) compared with the Total Frequency (TF, $\%$ ), which is the sum of all absolute frequencies. The Relative Dominance (RDo, \%) represents the percentage of ADo (absolute dominance of the species in question) related to the total dominance (TDo) (Araújo and Ferraz, 2010).

\section{Inventory in situ}

To obtain the data regarding species use, we applied the in situ inventory method (Lucena et al., 2013) in 61 residences in the community of São Francisco. First, there was contact with the homeowners (man or woman, in charge of the house, who was available at the time of the interview) to clarify the aim of the study. The informants were asked to sign the Free and Transparent Consent form that the National Health Council, through the Committee of Ethics in Research (Resolution No. 196/1996) requires. The Committee of Ethics in Research with Human Beings (CEP) of the Lauro Wanderley Hospital, Federal University of Paraíba, approved this study, registered in protocol CEP/HULW No. 297/2011.
We applied the inventory in situ in the residences, focusing on all plant material for energy purposes in the houses and external areas of the property, at the time of visit. During the observation the informants were asked about the name (vernacular) of the plant found in the firewood stock, charcoal source, as well as the frequency of collection of the material. After this first contact we visited the community monthly, over one year 12 months) in order to monitor the renewal dynamics of these items.

The material was recorded from photographs; the plants were collected and identified for a possible confirmation between vernacular names and the species. Subsequently, the harvested plants were deposited in the Herbarium Professor Jayme Coelho of the Federal University of Paraíba, in the Agricultural Science Center.

\section{Results}

\section{Vegetation inventory}

From the 15 species recorded in the inventory in situ, seven belonging to six genera and five families were found in the forest fragment studied. They are: Aspidosperma pyrifolium Mart. (pereiro) with 1,450 individuals, Croton blanchetianus Baill. (marmeleiro) with 1,181 , Poincianella pyramidalis Tul (catingueira) with 436, Mimosa ophthalmocentra Mart. ex Benth (Jurema de imbira) with 83, Miracrodruon urundeuva Allemão (aroeira) with 10, colubrina Anadenanthera colubrina (Vell.) Brenan (angico) with 8, and Sideroxylon obtusifolium (Roem \& Schult.) T. D. Penn (quixabeira) with only one individual (Table 1).

The most relevant botanical
families
Euphorbiaceae, and Fabaceae. This is explained by checking the large number of individuals included in these families.

Regarding the phytosociological parameters, we observed that $A$. pyrifolium obtained high values of relative importance and relative dominance (IV $=115.13$, $\mathrm{RDo}=45.53), \quad$ followed by C. blanchetianus $\quad(\mathrm{VI}=87.15$, 
$\mathrm{RDo}=26.30)$ and $P$. pyramidalis $(\mathrm{VI}=50.39, \mathrm{RDo}=15.03)$. The same was observed for relative density (RD) and relative frequency (RF), in which A. pyrifolium had $\mathrm{RD}=44.10$ and
$\mathrm{RF}=25.50$, C. blanchetianus $\mathrm{RD}=35.92$

and $\mathrm{RF}=24.93$, and $P$. pyramidalis

$\mathrm{RD}=13.26$ and $\mathrm{RF}=22.10$.

Table 1. Woody species with DGL $\geq 3 \mathrm{~cm}$ recorded in the forest fragment studied, with effective use for fuel in the Rural Community of São Francisco, Municipality of Cabaceiras (Paraíba State, Northeast Brazil).

\begin{tabular}{|c|c|c|c|c|c|}
\hline Taxa & No. Ind. & RD & $\mathbf{R F}$ & RDo & IV \\
\hline \multicolumn{6}{|l|}{ Anacardiaceae } \\
\hline Myracrodruon urundeuva Allemão (Aroeira) & 10 & 0.30 & 1.98 & 4.64 & 6.93 \\
\hline \multicolumn{6}{|l|}{ Apocynaceae } \\
\hline Aspidosperma pyrifolium Mart. (Pereiro) & 1,450 & 44.10 & 25.50 & 45.53 & 115.13 \\
\hline \multicolumn{6}{|l|}{ Euphorbiaceae } \\
\hline Croton blanchetianus Baill (Marmeleiro) & 1,181 & 35.92 & 24.93 & 26.30 & 87.15 \\
\hline \multicolumn{6}{|l|}{ Fabaceae } \\
\hline $\begin{array}{l}\text { Anadenanthera colubrina (Vell.) Brenan } \\
\text { (Angico) }\end{array}$ & 8 & 0.24 & 1.70 & 1.83 & 3.77 \\
\hline Poincianella pyramidalis Tul. (Catingueira) & 436 & 13.26 & 22.10 & 15.03 & 50.39 \\
\hline $\begin{array}{l}\text { Mimosa ophthalmocentra Mart. ex Benth. } \\
\text { (Jurema de imbira) }\end{array}$ & 83 & 2.52 & 5.10 & 2.01 & 9.63 \\
\hline \multicolumn{6}{|l|}{ Sapotaceae } \\
\hline $\begin{array}{l}\text { Sideroxylon obtusifolium (Roem \& Schult.) T. } \\
\text { D. Penn. (Quixabeira) }\end{array}$ & 1 & 0.03 & 0.28 & 0.01 & 0.32 \\
\hline
\end{tabular}

Results of phytosociological parameters, in which No. Ind $=$ number of individuals; RD $=$ relative density; $\mathrm{RF}=$ relative frequency; $\mathrm{RDo}=$ relative dominance; $\mathrm{IV}=$ importance value.

\section{Inventory in situ}

In total, 15 species, belonging to 14 genera and six plant families, were recorded for energy purposes, in the Rural Community of São Francisco, among which Fabaceae (8 spp) and Anacardiaceae (3 spp) were the most prominent, due to having greater diversity of species (Table 2).

In 54 of the 61 residences where we carried out the inventory, energy use was recorded, with an occurrence frequency of $88.5 \%$ for fuel category. We found two effective types of uses of timber resources for this purpose (firewood and charcoal). Among the total number of species, 11 are used exclusively as firewood, and four are used as firewood and also for the production of charcoal.

\section{Firewood use}

Among the 15 species observed in the firewood stock of the residences, the exotic species Prosopis juliflora (sw.) DC. (algaroba) had prominence, showing in the first month of the survey (July 2011) a use frequency of $32.79 \%$, followed by the native species $P$. pyramidalis (29.51\%), M. urundeuva (27.87\%), C. blanchetianus $(22.95 \%), A$. pyrifolium $(21.31 \%)$, and Mimosa tenuiflora (Willd.) Poir. (jurema preta) $(16.39 \%)$. The other species had use frequency below $3.29 \%$.

The first time, it was possible to register a greater wealth of species in the firewood stocks of the residences, and a high frequency of apparitions of these species. In the following months of inventory, there was a significant decrease in the diversity of species recorded, especially the species mentioned above, regarding the use of firewood, which remained always in the first six places, with changes only in December 2011 and April 2012, taking the place of the use of 
Craibeira (Tabebuia aurea (Silva Manso) Benth. \& Hook. f. ex S. Moore), which replaced the use of $M$. tenuiflora, and Piptadenia stipulaceae (Benth.) Ducke instead of A. pyrifolium (Table 3).
In some cases, the residents from the community, when carrying out maintenance on the fences on their farms, took the sticks (material removed from the fences) for the stock and subsequently used

Table 2. Species recorded for fuel purposes and their uses assigned in the Rural Community of São Francisco, Municipality of Cabaceiras (Paraíba State, Northeast Brazil).

\begin{tabular}{|c|c|c|}
\hline Family/Species & $\begin{array}{l}\text { Vernacular } \\
\text { name }\end{array}$ & Uses/Fuel \\
\hline \multicolumn{3}{|l|}{ Anacardiaceae } \\
\hline Myracrodruon urundeuva Allemão & Aroeira & firewood/charcoal \\
\hline Schinopsis brasiliensi Engl. & Braúna/Baraúna & firewood/charcoal \\
\hline Spondias tuberosa Arruda & Umbuzeiro & firewood \\
\hline \multicolumn{3}{|l|}{ Apocynaceae } \\
\hline Aspidosperma pyrifolium Mart. & Pereiro & firewood \\
\hline \multicolumn{3}{|l|}{ Bignoniaceae } \\
\hline Tabebuia aurea (Silva Manso) Benth. \& Hook. f. ex S. Moore & Craibeira & firewood \\
\hline \multicolumn{3}{|l|}{ Fabaceae } \\
\hline Croton blanchetianus Baill & Marmeleiro & firewood \\
\hline Anadenanthera colubrina (Vell.) Brenan & Angico & firewood \\
\hline Poincianella pyramidalis Tul. & Catingueira & firewood/charcoal \\
\hline Piptadenia stipulaceae (Benth.) Ducke & Jurema branca & firewood \\
\hline Mimosa ophthalmocentra Mart. ex Benth. & $\begin{array}{l}\text { Jurema de } \\
\text { imbira }\end{array}$ & firewood \\
\hline Mimosa tenuiflora (Willd.) Poir. & Jurema preta & firewood \\
\hline $\begin{array}{l}\text { Leucaena leucocephala (Lam.) de Wit [L. glauca (L.) Benth.] } \\
\text { cv Peru }\end{array}$ & Leucena & firewood \\
\hline Prosopis juliflora (sw.) DC. & Algaroba & firewood/charcoal \\
\hline \multicolumn{3}{|l|}{ Sapotaceae } \\
\hline \multicolumn{2}{|l|}{ Cactaceae } & firewood \\
\hline Pilosocereus pachycladus F. Ritter & Facheiro & firewood \\
\hline
\end{tabular}

them in domestic stoves, so there was no record of firewood purchase, just collection. We observed a preference for dry firewood collection, conducted mostly once a week by homeowners.

\section{Charcoal use}

In the first visit, we recorded a frequency of $70.49 \%$ of charcoal use, and among the 15 species recorded, we identified the use of four: P. juliflora (frequency $=57.38 \%), \quad P$. pyramidalis (frequency $=8.20 \%$ ), M. urundeuva (frequency $=3.28 \%$ ), and Schinopsis brasiliensis Engl. (Baraúna) (frequency $=1,64 \%$ ). During every month of monitoring, the most relevant species, for this purpose, was $P$. juliflora, used during three months along with $P$. pyramidalis (Table 4).

Over the course of study, we noticed an oscillation regarding the renewal of charcoal stocks; the initial frequency decreased to $14.55 \%$ in October, remaining stable during the other months of study, ranging only from $22.95 \%$ to $14.55 \%$. The charcoal is produced in the community by some of its residents for family use, and only one informant produces charcoal to be sold in the region. 


\section{Use of liquefied petroleum gas (LPG) combined with phytofuels}

In the Community Rural of São Francisco, the reasons for the constant use of wood as an energy source were associated with traditional and economic issues. The ease of obtaining timber, combustion property, and the high cost of LPG cylinders reinforce this practice.

In 7 of the 61 residences in which we conducted the inventory, firewood use was not recoded, while in one residence the

Table 3. Monthly reviews of firewood stocks of the residences in the Rural Community of São Francisco, Municipality of Cabaceiras (Paraíba State, Northeast Brazil).

\begin{tabular}{|c|c|c|c|c|c|c|c|c|c|c|c|c|}
\hline \multirow{3}{*}{ Species } & \multicolumn{12}{|c|}{ Monthly reviews of firewood } \\
\hline & Jul & Aug & Sept & Oct & Nov & Dec & Jan & Fev & Mar & Apr & May & Jun \\
\hline & 2011 & & & & & & 2012 & & & & & \\
\hline $\begin{array}{l}\text { Anadenanthera colubrina } \\
\text { (Vell.) Brenan (Angico) }\end{array}$ & $\mathrm{X}$ & $\mathrm{X}$ & & & & & & & & & & \\
\hline $\begin{array}{l}\text { Aspidosperma pyrifolium } \\
\text { Mart. (Pereiro) }\end{array}$ & $\mathrm{X}$ & $\mathrm{X}$ & $\mathrm{X}$ & $\mathrm{X}$ & $\mathrm{X}$ & $\mathrm{X}$ & $\mathrm{X}$ & $\mathrm{X}$ & $\mathrm{X}$ & $\mathrm{X}$ & $\mathrm{X}$ & $\mathrm{X}$ \\
\hline $\begin{array}{l}\text { Croton blanchetianus Baill } \\
\text { (Marmeleiro) }\end{array}$ & $\mathrm{X}$ & $\mathrm{X}$ & $\mathrm{X}$ & $\mathrm{X}$ & $\mathrm{X}$ & $\mathrm{X}$ & $\mathrm{X}$ & $\mathrm{X}$ & $\mathrm{X}$ & $\mathrm{x}$ & $\mathrm{X}$ & $\mathrm{X}$ \\
\hline $\begin{array}{l}\text { Leucaena leucocephala } \\
\text { (Lam.) de Wit [L. glauca (L.) } \\
\text { Benth.] cv Peru (Leocena) }\end{array}$ & $\mathrm{X}$ & $\mathrm{X}$ & & & & & & & & & & \\
\hline $\begin{array}{l}\text { Mimosa ophthalmocentra } \\
\text { Mart. ex Benth. (Jurema de } \\
\text { Imbira) }\end{array}$ & $\mathrm{X}$ & $\mathrm{X}$ & $\mathrm{X}$ & $\mathrm{X}$ & $\mathrm{X}$ & & $\mathrm{X}$ & $\mathrm{X}$ & $\mathrm{X}$ & $\mathrm{X}$ & $\mathrm{X}$ & $\mathrm{X}$ \\
\hline $\begin{array}{l}\text { Mimosa tenuiflora (Willd.) } \\
\text { Poir. (Jurema Preta) }\end{array}$ & $\mathrm{X}$ & & & & & & & & & & & \\
\hline $\begin{array}{l}\text { Myracrodruon urundeuva } \\
\text { Allemão (Aroeira) }\end{array}$ & $\mathrm{X}$ & $\mathrm{X}$ & $\mathrm{X}$ & $\mathrm{X}$ & $\mathrm{X}$ & $\mathrm{X}$ & $\mathrm{X}$ & $\mathrm{X}$ & $\mathrm{X}$ & $\mathrm{X}$ & $\mathrm{X}$ & $\mathrm{X}$ \\
\hline $\begin{array}{lr}\text { Piptadenia } & \text { stipulaceae } \\
\text { (Benth.) Ducke } \quad \text { (Jurema }\end{array}$ & $\mathrm{X}$ & $\mathrm{X}$ & & & & & & & & $\mathrm{X}$ & & \\
\hline Branca) & & & & & & & & & & & & \\
\hline $\begin{array}{l}\text { Pilosocereus pachycladus F. } \\
\text { Ritter (Facheiro) }\end{array}$ & $\mathrm{X}$ & & & & & & & & & & & \\
\hline $\begin{array}{l}\text { Poincianella pyramidalis Tul. } \\
\text { (Catingueira) }\end{array}$ & $\mathrm{X}$ & $\mathrm{X}$ & $\mathrm{X}$ & $\mathrm{X}$ & $\mathrm{X}$ & $\mathrm{X}$ & $\mathrm{X}$ & $\mathrm{X}$ & $\mathrm{X}$ & $\mathrm{X}$ & $\mathrm{X}$ & $\mathrm{X}$ \\
\hline $\begin{array}{l}\text { Prosopis juliflora (sw.) DC. } \\
\text { (Algaroba) }\end{array}$ & $\mathrm{X}$ & $\mathrm{X}$ & $\mathrm{X}$ & $\mathrm{X}$ & $\mathrm{X}$ & $\mathrm{X}$ & $\mathrm{X}$ & $\mathrm{X}$ & $\mathrm{X}$ & $\mathrm{X}$ & $\mathrm{X}$ & $\mathrm{X}$ \\
\hline $\begin{array}{l}\text { Sideroxylon obtusifolium } \\
\text { (Roem \& Schult.) T. D. Penn. } \\
\text { (Quixabeira) }\end{array}$ & $\mathrm{X}$ & & & & & & & & & & & \\
\hline $\begin{array}{l}\text { Spondias tuberosa Arruda } \\
\text { (Umbuzeiro) }\end{array}$ & $\mathrm{X}$ & & & & & & & & & & & \\
\hline $\begin{array}{l}\text { Schinopsis brasiliensi Engl. } \\
\text { (Baraúna) }\end{array}$ & $\mathrm{X}$ & & & & & & & & & & & \\
\hline Tabebuia aurea (Silva & & & & & & & & & & & & \\
\hline $\begin{array}{l}\text { Manso) Benth. \& Hook. f. ex } \\
\text { S. Moore (Craibeira) }\end{array}$ & $\mathrm{X}$ & & $\mathrm{X}$ & & & $\mathrm{X}$ & & & & & & \\
\hline
\end{tabular}


Table 4. Monthly review of coal stocks in the households of the Rural Community of São Francisco, Municipality of Cabaceiras (Paraíba, Northeast Brazil). Where (x) indicates the presence of the species.

\begin{tabular}{|c|c|c|c|c|c|c|c|c|c|c|c|c|}
\hline \multirow{3}{*}{ Species } & \multicolumn{12}{|c|}{ Monthly review of coal stocks } \\
\hline & Jul & Agu & Sept & Oct & Nov & Dec & Jan & Feb & Mar & Apr & May & Jun \\
\hline & 2011 & & & & & & 2012 & & & & & \\
\hline $\begin{array}{l}\text { Myracrodruon urundeuva } \\
\text { Allemão (Aroeira) }\end{array}$ & $\mathrm{x}$ & & & & & & & & & & & \\
\hline $\begin{array}{l}\text { Poincianella pyramidalis Tul. } \\
\text { (Catingueira) }\end{array}$ & $\mathrm{x}$ & $\mathrm{x}$ & & & & & & & & & & \\
\hline $\begin{array}{l}\text { Prosopis juliflora (sw.)DC. } \\
\text { (Algaroba) }\end{array}$ & $\mathrm{X}$ & $\mathrm{x}$ & $\mathrm{x}$ & $\mathrm{x}$ & $\mathrm{x}$ & $\mathrm{x}$ & $\mathrm{x}$ & $\mathrm{x}$ & $\mathrm{x}$ & $\mathrm{x}$ & $\mathrm{x}$ & $\mathrm{x}$ \\
\hline $\begin{array}{l}\text { Schinopsis brasiliensi Engl. } \\
\text { (Baraúna) }\end{array}$ & $\mathrm{x}$ & & & & & & & & & & & \\
\hline
\end{tabular}

informant reported that the non-use of firewood was because of her respiratory problems caused by allergic reaction to smoke produced by the burning of wood. Therefore, liquefied petroleum gas (LPG) was used. The other six residences were newly built and inhabited by young couples, who used only LPG because of its practicality.

We recorded the use of LPG in $100 \%$ of the inventoried residences. The combined use of energy sources was recorded in 54 residences; in 16 of them there was also the use of firewood, in 19 there was the use of charcoal too, and in the other 19 residences we recorded the use of charcoal and firewood together.

\section{Discussion}

\section{Vegetation inventory}

The botanical and ethnobotanical technique for collection may assist considerably in the cataloging of natural resources, and is effective in understanding the dynamics of use and availability of local flora in many regions of the Caatinga (Albuquerque and Andrade, 2002ab; Florentino et al., 2007; Ramos et al., 2008; Guerra et al., 2012; Leite et al., 2012; Lucena et al., 2014).

Lucena et al. (2013), in an ethnobotanical study conducted in two rural communities, using the inventory in situ method in the forest fragment of Barrocas and Cachoeira (Northeast Brazil), observed the same prominent families and species we identified in the vegetation of Community Rural of São Francisco.

Aspidosperma pyrifolium and $P$. pyramidalis, C. blanchetianus, which had prominence in Cabaceiras Municipallity, are typically found in abundance in other areas of the Semiarid Region (Lucena et al., 2008; Guerra et al., 2012). This prominence can be attributed to their particular characteristics, such as resistance to long dry periods, and adaptation in shallow and stony soils, which means they are easily found (Maia, 2004).

Aspidosperma pyrifolium and $C$. blanchetianus were found in significant number in the vegetation fragment of Cabaceiras. Therefore, these species are not at risk and do not need immediate conservation, but should be used sustainably to prevent a future critical condition in vegetation, as has already happened locally with other species. These species have been mentioned as prominent in other ethnobotanical studies that present phytosociological information (Carvalho et al., 2012; Leite et al., 2012).

On the other hand, we verified a small number of $A$. colubrina and M. urundeuva, with eight and 10 individuals, respectively, in the forest fragment studied. Such data deserve special attention, because this reality is evident in other studies (Lucena et al., 2011; Silva et al., 2014), which mention some species at risk, such as $M$. urundeuva that has already been added to the list of endangered species of the Environment Ministry, according to 
Normative Instruction No. 06, of Sept. 23, 2008.

\section{Inventory in situ}

The inventory in situ method records the plant resources found in the residence at the time of the visit, providing information about the real and current use of the plants. One advantage of using this method is not depending on interviews for studies that focus on timber uses. Some studies have already been carried out employing this technique, such as those conducted by de Gaugris et al. (2006), Albuquerque et al. (2008), Lucena et al. (2013), Medeiros (2010), and Ramos et al. (2012). The use of timber resources as fuel is a common practice in many rural communities, among the most diverse populations, and is evidenced in several studies conducted mainly in the Caatinga ecosystem (Cocks and Wiersum, 2003; Pérez-Negron and Casas 2007; VenturaAquino et al., 2008; Lucena et al., 2013; Medeiros, 2010; Ramos et al., 2012)

The wood used for firewood and charcoal should be considered one of the most important fuels, since according to the estimates of FAO (1985) and Brito and Cintra (2004), at least two of every six people use the wood as the main source of energy. This information was consistent with the survey conducted in Cabaceiras Municipality, where $88.5 \%$ of the people from the community made use of wood for this purpose in their homes.

The data we recorded in Cabaceiras Municipality were similar to those that Ramos et al. (2012) recorded for algaroba ( $P$. juliflora), aroeira (M. urundeuva), catingueira $(P$. pyramidalis), marmeleiro (C. blanchetianus), pereiro (A. pyrifolium), and jurema preta (M. tenuiflora) in the Communities of Barrocas and Cachoeira, Municipality of Soledade, in Paraíba, Northeast Brazil. This can be explained by the similar climatic and vegetation characteristics of the communities, since they are next to each other.

\section{Firewood use}

Timber extraction, ranked as the largest generator of goods and services in the Caatinga, has been extensive and, therefore, concerning due to the major impacts on the native species of this ecosystem (Braid, 1996; Silva et al., 2014). Thus, it is important to notice that about $80 \%$ of the wood is consumed for energy propose, making this sector the largest extractive pressure generator in northeast Brazil (Brito, 1997; Sampaio and Guamarra-Rojas, 2002).

Many studies have pointed out the importance of using firewood to meet the energy needs in rural populations (Albuquerque and Andrade, 2002; Rodrigues et al., 2002; Ferraz, 2004; Fonseca-Kruel and Peixoto, 2004). However, information is almost always limited to broad ethnobotanical inventories that are restricted to lists of species used in this category. Studies regarding the consumption of firewood can produce inaccurate results, since these studies analyze the dynamics of use without considering the different species, from the most durable and regular (Ramos et al., 2012). However, it is important to add that interviews are more technical, with respect to knowledge, such as that related to the preferred species or the most sought after in a short period of time. Based on this assumption, the inventory in situ conducted in the community of São Francisco, for 12 months, made it possible to obtain a list of species actually used as firewood in the region (15 spp) - 13 native species and two exotic species.

The diversity of species in firewood stocks in the inhabitants' residences of São Francisco did not change over the year (2011) when the inventory was carried out. This may be explained by the fact that 2011 was an atypical year, with high temperatures and low rainfall, which according to AESA (Executive Agency for Water Management of Paraíba State) was an average rainfall of $27.5 \mathrm{~mm}^{3}$.

In contrast to Ramos et al. (2012) in their survey conducted in Soledade Municipality, our study was not conducted during the rainy season, preventing comparisons between opposite climatic periods. However, both studies recorded in firewood stocks a particular species wealth, 
in all reviews, for $P$. juliflora, C. blanchetianus, M. tenuiflora, M. urundeuva, and P. pyramidalis.

Several factors may influence the choice of species used as firewood, as well as the renewal of their stocks, such as the influence of seasonal factors, which, as regards the region and the population concerned, can generate different responses, as stated by Ramos (2007).

According to Shankar et al. (1998), in India during the rainy season, the use of firewood increased due to the increase in consumption of hot drinks. In contrast, Campbell et al. (1997) reported that in Zimbabwe residents were relatively free from agricultural work during the dry season, so forest products were the focus. However, in a study conducted by Ramos et al. (2008) in Caruaru Municipality (Northeast Brazil), most of the informants stated that firewood was preferably harvested in the summer $(95 \%)$, and the main reason for this seasonal standard was the ease entering and moving in the forest during the dry season. Similar information was recorded in the Community Rural of São Francisco.

Regarding the consumption standards, dry wood was the most used, because according to the informants it emits less smoke when burnt and its properties facilitate combustion. According to the literature, this preference seems to be prevalent in studies on this topic (Campbell et al., 1997; Nagothu, 2001; Tabuti and Dhilliona, 2003; Medeiros, 2010).

With regard to the frequency of firewood collection, differences were observed over a few months; some informants reported that the firewood collected in a previous month was sufficient to meet the needs for cooking. This confirms Medeiros (2010) observation that while some people prefer to collect small amounts of firewood and increase the frequency of collection, others collect large amounts of wood for storage, thus, decreasing the frequency of collection.

The use of firewood in the home is closely related to groups of species that are preferred by people who collect them
(Campbeel, 1988; Grundy et al., 1993). The preference for firewood can be explained by its fuel value index (FVI), which is considered an important tool to classify species according to the physical properties of their wood, such as $M$. tenuiflora, C. blanchetianus, and P.pyramidalis, recorded in all reviews of the firewood stocks in the Community Rural of São Francisco. These species had prominence in the study conducted by Ramos (2008), in which $M$. tenuiflora had high density value, C. blanchetianus had one of the lowest moisture, and higher FVI, and $P$. pyramidalis had one of the highest FVI. $P$. juliflora was also prominent in the study conducted by Ramos (2007), although it is an exotic species of the Caatinga, occupying sixth place in terms of FVI, and characterizing it as one of the best phytofuels from a scientific point of view.

Another relevant factor for the continued use of firewood for cooking concerns traditional and economic issues, as most of the residents from the community are farmers and retirees, who have adopted the use of firewood from their ancestors, as well as the accessibility and the local availability of resources, which was also observed by Samant et al. (2000) in the Himalayan region. The contribution of cultural elements for the continuity of the tradition of using firewood has been shown in some studies that evidence a preference for foods cooked in wood stoves, such as sweets, beans, and meats (Cocks and Wiersum, 2003; Ventura-Aquino et al., 2008).

For live wood extraction, the use of $P$. juliflora, although it is an exotic species that grows rapidly in time and space, according to Pegado et al. (2006), can be an alternative to minimize the extraction of native species, in view of the fact it is found in large quantities in the community studied. However, from an ecological point of view of biological invasion, $P$. juliflora, due to its allelopathic substances, can be a problem for vegetation formations in the Caatinga, which are in constant succession stage due to anthropogenic activities and, therefore, vulnerable. 


\section{Charcoal use}

Charcoal and firewood are vital phytofuels to support the cooking processes in rural families from many communities around the world, as well as, importantly, to support drying and fermentation processes, and the production of electricity (FAO, 1985, 2003; Biran et al., 2004; Brouwer and Falcão, 2004). This importance was verified in the Rural Community of São Francisco, given that $62.28 \%$ of the community make use of this resource for cooking. The data are relevant compared with those reported by Ramos (2007) in Caruaru Municipality, Pernambuco State, in which only about $37 \%$ of the families depended on charcoal for cooking, using it at times in conjunction with other fuels. Another difference between Ramos' study and ours is that the charcoal consumed in Caruaru is from the State of Paraíba, thus apparently not impacting the local vegetation; in our study the charcoal used comes from the local vegetation, produced by some of the residents for their own consumption, and produced and sold by one resident.

In the in situ record appeared four species for the production of charcoal, but only $P$. juliflora and $P$. pyramidalis remained in use for this purpose over the months. The first was present in the stocks during the 12 months, while the second was found in only four months. In informal conversations with the residents, they stated that the charcoal consumed was made from $P$. juliflora; because it is an exotic species, its use can be explained by the legislation that forbids the cutting of native wood from Caatinga, and the regular visits of IBAMA (Brazilian Institute for the Environment) to the community, since it is near a release region of captured wild animals, which contribute to the non-use of native species. Medeiros (2010) in a study conducted in the Community of Três Ladeiras in Iguarassu in the Pernambuco State, observed changes in the behavior of some residents due to the prohibition of the regular use of native wood. We can note that in the Rural Community of São Francisco, the fact that $P$. juliflora meets the energy needs of the community suggests that it is an option to reduce the extraction of native species, minimizing the impact caused by the constant use of phytofuels. Besides its essential use, due to the supervision, $P$. juliflora also has a high fuel value index (FVI), according to Ramos (2007). Another factor that can influence this continuous use is its accessibility and availability in the community, as noted by Samant et al. (2000) in the Himalayas.

However, some informants, over the last months of our study, admitted that in charcoal production, in some cases, there is use of other woods, especially of $M$. urundeuva due to the burning properties of the final product. This species was in the list of endangered species according to the Normative Instruction $\mathrm{N}^{\mathrm{o}}$. 06 of September 23, 2008 (Lucena et al., 2011). Some ethnobotanical studies have been conducted focusing on this species, which is well known for its many properties that meet the subsistence needs of rural populations in semiarid region (Albuquerque and Andrade, 2002a,b; Albuquerque and Lucena, 2005; Monteiro et al., 2006a; Albuquerque and Oliveira, 2007; Lucena et al., 2007; Oliveira et al., 2007; Lucena et al., 2008; Monteiro et al., 2008; Ramos et al., 2008a,b; Lucena et al., 2013). The use of M. urundeuva as fuel is also recorded both in charcoal production and as firewood (Ramos et al., 2008a,b; Sá et al., 2009; Lucena et al., 2013).

In the study area, these uses may differ in current use, when the informant confirms the use, and potential use when the informant knows the use, but does not employ it, as in the studies conducted by Sousa et al. (2012), Sá et al. (2009), and Lucena et al. (2013). This may be indicative of the need for more studies focused on the fuel category, in particular for M. urundeuva. Regarding the renewal of the community's charcoal stocks, and corroborating Sanga (2004), who notes the durability of this product which does not spoil when stored for a long period, the residents of Community Rural of São Francisco reported storage and use of charcoal during long periods, precisely because of combined use with other sources, which, according to Ramos (2007), forms a relay system of energy sources in 
the residences. This renewal of stocks when we analyzed its frequency in residences showed an oscillation of $70.49 \%$ in July 2011, to $14.55 \%$ in October.

\section{Use of liquefied petroleum gas} combined with phytofuels

In many parts of the world the association of phytofuels with non-forest energy sources is common (Bensel and Remedio, 1995; Brouwer and Falcão, 2004). Decisive criteria regarding the use of energy source are related to issues such as culture, family economy, and availability of the sources. This fact was recorded in the present study, showing that the use of LPG is very widespread in the community. In some regions of India, the use of LPG has been recorded, but this fact does not diminish the importance of forest fuels in these regions (Misra et al., 1995).

The use of LPG is common in a large part of Latin America, especially in Brazil, where almost all families have access to gas, even in remote areas (WLPGA, 2004). In the community of São Francisco in $100 \%$ of residences LPG was used, in some cases combined with firewood and/or charcoal which correspond to $88.5 \%$. Moraes et al. (2008) in a study conducted in the semiarid region of Piauí (northeast Brazil) found equivalent results, noting that there were gas cylinders in $80 \%$ of the residences. However, the gas was intended only to prepare foods that cook faster, while for foods which take longer time, such as bean, the residents used firewood.

This combined use is considered by the informants as a way to reduce household expenses. Similar practices were observed in other studies (Medeiros, 2010; Ramos et al. 2012). The presence of a gas stove in the home was also recorded in studies conducted in Mexico (Cocks and Wiersum, 2003; Pérez-Négron and Villas, 2007; Ventura-Aquino et al., 2008), but this did not replace or diminish the importance of firewood and charcoal. The pattern of simultaneous use of firewood and cooking gas, as in this study, was noted by Ramos et al. (2008) in studies conducted in the Semiarid Northeast. In Maputo et al. (2004) also pointed out that the sources of energy most used for cooking were wood and fossil fuels.

\section{Conclusions}

This study evidenced the effective use of timber resources for energy purposes in the Rural Community of São Francisco, Municipality of Cabaceiras. Although we recorded the use of LPG in tall inventoried residences, the use of firewood and charcoal for cooking was not affected, given that the use of these phytofuels was recorded in $88.5 \%$ of the inventoried residences. The most recorded species in firewood stocks were C. blanchetianus, A. pyrifolium, $M$. tenuiflora, $P$. pyramidalis, $M$. urundeuva, and $P$. juliflora, with the latter three species also used in the production of charcoal. P. juliflora appears as an option to minimize the pressure due to the constant collection of native wood, which is really important for the community that uses it.

The use of $M$. urundeuva was important given that it is an endangered species; the data collected may be an indication of possible conservation activities as only 10 individuals were recorded in the forest fragment studied. The inventory in situ was an important tool for obtaining information about the real use of the resources in the residences, which complements ethnobotanical studies that record the knowledge and preferences of traditional populations for phytofuels.

\section{Conflict of interest statement}

Authors declare that they have no conflict of interests.

\section{References}

Albuquerque, F. J. B.; Lobo, R. J. S. Análise das repercussões psicossociais decorrentes da concessão de benefícios rurais. Psicologia: Reflexão e Crítica, v. 12, p. 503-519, 1999.

Albuquerque, U. P. Folhas Sagradas: as plantas litúrgicas e medicinais nos cultos afrobrasileiros. 1. ed. Recife, Editora UFPE, 1997. 
Albuquerque, U. P.; Andrade, L. H. C. Conhecimento botânico tradicional e conservação em uma área de Caatinga no Estado de Pernambuco, no Nordeste do Brasil. Acta Botânica Brasílica, v. 16, n. 3, 273-285, 2002a.

Albuquerque, U. P.; Andrade, L. H. C. Uso de recursos vegetais da Caatinga: o caso do agreste do Estado de Pernambuco (Nordeste do Brasil). Interciencia, v. 27, p. 336-345, 2002 b.

Albuquerque, U. P.; Andrade, L. H. C.; Silva, A. C. O. Use of plant resources in a seasonal dry forest (Northeastern Brazil). Acta Botânica Brasílica, v. 19, p. 27-38, 2005.

Albuquerque, U. P.; Araújo, T. A. S.; Ramos, M. A.; Nascimento, V. T.; Lucena, R. F. P.; Monteiro, J. M.; Alencar, N. L.; Araújo, E. L. How Ethnobotany can aid biodiversity conservation: reflections on investigations in the Semi-Arid Region of NE Brazil. Biodiversity and Conservation, v. 18, n. 1, p. 127-150, 2008.

Albuquerque, U. P.; Oliveira, R. F. Is the use impact on native Caatinga species in Brazil reduced by the high species richeness of medicinal plants? Journal of Ethnopharmacology, v. 113, p. 156-170, 2007.

Alves, J. J. A., Souza, E. N., Araújo, M. A. Estudo descritivo da tipologia turística do Município de Cabaceiras - Paraíba. Caderno Virtual de Turismo, v. 8, no. 3, p. 86-103, 2008.

Araújo, E. L.; Ferraz, E. M. N. Amostragem da vegetação nos estudos etnobotânicos. In: Albuquerque, U. P.; Lucena, R. F. P.; Cunha, L. V. F. C. (Eds.). Métodos e técnicas na pesquisa Etnobiológica e Etnoecológica. Recife: Núcleo Publicações em Ecologia e Etnobotânica Aplicada, 2010. p. 223-253.

Balick, M. J.; Cox, P. A. Plants, people and culture. New York: Scientific American Library, 1996.

Braid, E. C. Importância sócio-econômica dos recursos florestais no nordeste do Brasil. Anais do I Seminário Nordestino sobre Caatinga, João Pessoa, 1996.

Brouwer, R.; Falcão, M. P. Wood fuel consumption in Maputo, Mozambique. Biomass and Bioenergy, v. 27, p. 233-245, 2004.

Berlin, B. Ethnobiological classification: principles of categorization of plants and animals in traditional societies. Princeton, USA: Princeton University Press, 1992.
Bensel, T. G.; Remedio, E. M. Residential energy use patterns in Cebu City, Philippines. Energy, v. 20, p. 173-187, 1995.

Biran, A.; Abbot, J.; Mace, R. Families and firewood: A comparative analysis of the costs and benefits of children in firewood collection and use in two rural communities in SubSaharan Africa. Human Ecology, v. 32, p. 1-25, 2004.

Brito, J. O. Fuelwood utilization in Brazil. Biomass and Bioenergy, v. 12, n. 1, p. 69-74, 1997.

Brito, J. O.; Cintra, T. C. Madeira para energia no Brasil: realidade, visão estratégia e demanda de ações. Biomass and Bioenergy, v. 1, n. 2, p. 157-163, 2004.

Carvalho, T. K. N.; Sousa, R. F.; Meneses, S. S. S.; Ribeiro, J. P. O.; Felix, L. P.; Lucena, R. F. P. Plantas usadas por uma comunidade rural na Depressão Sertaneja no Nordeste do Brasil. Revista de Biologia e Farmácia Biofar, v. especial, p. 92-119, 2012.

Campbell, B.; Dutoit, R. Relationships between wood resources and use of species for construction and fuel in the communal lands of Zimbabwe. Monographs in Systematic Botany Missouri Botanical Gardens, v. 25, p. 331341, 1988.

Cocks, M. L.; Wiersum, K. F. The significance of plant diversity to rural households in Eastern Cape Providence of South Africa. Forests, Trees and Livelihoods, v. 13, p. 39-58, 2003.

Dahdouh-Guebas, F.; Collin, S.; Senn, D.; Rönnbäck, P.; Depommier, D.; Ravishhankar, T.; Koedam, N. Analyzing ethnobotanical and fishery-related importance of mangroves of the East-Godavari Delta (Andhra Pradesh, India) for conservation and management purposes. Journal of Ethnobiology and Ethnomedicine, v. 142, n. 1, p. 16-28, 2006.

Diegues, A. C.; Arruda, R. S. V. Saberes tradicionais e biodiversidade no Brasil. Brasília: Ministério do Meio Ambiente, São Paulo: USP, 2001. (Biodiversidade, 4).

FAO. Madera para producir energia. Roma: FAO, 1985. (Informe sobre Cuestiones Florestalis, 1).

FAO. Wood Energy. Promoting sustainable energy systems. Rome: FAO, Forest Products Division, 2003.

Ferraz, J. S. F.; Meunier, I. M. J.; Albuquerque, U. P. Conhecimento sobre espécies lenhosas úteis da mata ciliar do Riacho do Navio, Floresta, Pernambuco. Zonas Áridas, v. 9, p. 27-39, 2005. 
Ferraz, J. S. F.; Albuquerque, U. P.; Meunier, I. M. J. Valor do uso e estrutura da vegetação lenhosa às margens do Riacho do Navio, Floresta, PE, Brasil. Acta Botânica Brasílica, v. 20, p. 25-134, 2006.

Fonseca-Kruel, V. S.; Peixoto, A. L. Etnobotânica na Reserva Extrativista Marinha do Arraial do Cabo, RJ, Brasil. Acta Botânica Brasílica, v. 18, p. 177-190, 2004.

Ford, R. I. An ethnobiology source book: the use of plants and animals by American Indians. New York: Garland Publishing, 1978.

Florentino, A. T. N.; Araújo, E. L.; Albuquerque, U.P. Contribuição de quintais agroflorestais na conservação de plantas da Caatinga, Município de Caruaru, PE, Brasil. Acta Botânica Brasílica, v. 21, n. 1, p. 37-47, 2007.

Gaugris, J. Y.; Van Rooyen, M. W. Questionnaires do not work a comparison of methods used to evaluate the structure of buildings and wood used in rural households, South Africa. Ethnobotany Research and Applications, v. 4, p. 119-131, 2006.

Galeano, G. Forest use at the Pacific Coast of Chocó, Colômbia: a quantitative approach. Economic Botany, v. 54, p. 358-376, 2000.

Gavin, M. C.; Anderson, G. J. Testing a rapid quantitative ethnobiological technique: first steps towards developing a critical conservation tool. Economic Botany, v. 59, p. 112-121, 2005.

Guerra, N. M.; Ribeiro, J. E. S.; Carvalho, T. K. N.; Pedrosa, K. M.; Felix, L. P.; Lucena, R. F. P. Usos locais de espécies vegetais nativas em uma comunidade rural no semiárido nordestino (São Mamede, Paraíba, Brasil). Revista de Biologia e Farmácia - Biofar, v. Especial, p. 141-211, 2012.

Grundy, I.; Campbell, B.; Balebereho, S.; Cunliffe, R.; Tafangenyasha, C.; Fergusson, R.; Parry, D. Availabilty and use of trees in Mutanda Resettlement Area, Zimbabwe. Forest Ecology and Management, v. 56, p. 243-266, 1993.

Hanazaki, N.; Souza, V. C.; Rodrigues, R. R. Ethnobotany of rural people from the boundaries of Carlos Botelho State Park, São Paulo State, Brazil. Acta Botânica Brasílica, v. 20, p. 899-909, 2006.

IBGE. Instituto Brasileiro de Geografia e Estatística. Available from: $<$ http://www.ibge.gov.br/home/presidencia/notí cias/notícia_visualiza.php?id_notícia $=169>$.

Accessed in: jan. 21, 2013.
Kvist, L. P.; Andersen, M. K.; Stagegaard, J.; Hesselsoe, M.; Llapapasca, C. Extraction from woody forest plants in flood plain communities in Amazonian Peru: use, choice, evaluation and conservation status of resources. Forest Ecology and Management, v. 150, p. 147-174, 2001.

La Torre-Cuadros, M. A.; Islebe, G. A. Traditional ecological knowledge and use of vegetation in Southeastern Mexico: a case study from Solferino, Quintana Roo. Biodiversity and Conservation, v. 12, p. 2455-2476, 2003.

Leal, I. R.; Silva, J. M. C.; Tabarelli, M.; Lacher, J. R. T. E. Mudando o curso da conservação da biodiversidade na Caatinga do Nordeste do Brasil. Megadiversidade, v. 1, n. 1, p. 139-146, 2005.

Leite, A. P.; Pedrosa, K. M.; Lucena, C. M.; Carvalho, T. K. N.; Félix, L. P.; Lucena, R. F. P. Uso e conhecimento de espécies vegetais úteis em uma comunidade rural no Vale do Piancó (Paraíba, Nordeste, Brasil). Revista de Biologia e Farmácia - Biofar, v. Especial, p. 133-157, 2012.

Lucena, R. F. P.; Araujo, E. L.; Albuquerque, U. P. Does the use-value of woody plants of the Caatinga (Northeastern Brazil) explain their local availability. Economic Botany, v. 61, p. 347-361, 2007a.

Lucena, R. F. P.; Albuquerque, U. P.; Monteiro, J. M.; Almeida, C. F. C. B. R.; Florentino, A. T. N.; Ferraz, J. S. F. Useful plants of the Semi-Arid Northeastern Region of Brazil - a look at their conservation and sustainable use. Environmental Monitoring and Assessment, v. 125, p. 281-290, 2007 b.

Lucena, R. F. P.; Nascimento, V. T.; Araújo, E. L.; Albuquerque, U. P. Local uses of native plants in an area of caatinga vegetation (Pernambuco, NE-Brazil). Ethnobotany Research and Applications, v. 6, p. 3-13, 2008.

Lucena, R. F. P.; Farias, D.; Carvalho, T. K. N.; Lucena, C. M.; Vasconcelo Neto, C. F. A.; Albuquerque, U.P. Uso e conhecimento tradicional da aroeira (Myracrodruon urundeuva) por comunidades tradicionais no Semiárido brasileiro. Sitientibus, Série Ciências Biológicas, v. 11, n. 2, p. 255-264, 2011.

Lucena, R. F. P.; Lucena, C. M.; Araújo, E. L.; Alves, A. G. C.; Albuquerque, U. P. Conservation priorities of useful plants from different techniques of collection and analysis of ethnobotanical data. Anais da Academia Brasileira de Ciências, v. 85, p. 169-186, 2013. 
Lucena, R. F. P.; Sousa, R. F.; Guerra, N. M.; Ribeiro, J. E. S.; Leite, A. P.; Abreu, D. B. O.; Carvalho, T. K. N.; Trovão, D. M. B. M.; AlveS, C. A. B.; Alves, R. R. N.; Borges, P. F.; Andrade, L. A.; Souto, J. S.; Sousa Júnior, S. P.; Nunes, E. N. The ecological apparency hypothesis and dry tropical forests: an ethnobotanical assessment. Etnoecológica, v. 10, n. 9, p. 1-17, 2014.

Lucena, C. M.; Costa, G. M.; Sousa, R. F.; Carvalho, T. K. N.; Marreiros, N. A.; Alves, C. A. B.; Pereira, D. D.; Lucena, R. F. P. Conhecimento local sobre cactáceas em comunidades rurais na Mesorregião do Sertão da Paraíba (Nordeste, Brasil). Biotemas, v. 25, n. 3, p. 279-289, 2012.

Luoga, E. J.; Witkowski, E. T. E.; Balkwill, K. Differential utilization and ethnobotany of trees in Kitulanghalo Forest Reserve and surrounding communal lands, Eastern Tanzania. Economic Botany, v. 3, n. 54, p. 328-343, 2000.

Maia, G. N. Caatinga: árvores e arbustos e suas utilidades. 1. ed. São Paulo: DeZ Computação Gráfica e Editora, 2004.

Martins, A. C. M.; Bernard, E.; Gregorin, R. Inventários biológicos rápidos de morcegos (Mammalia, Chiroptera) em três unidades de conservação do Amapá, Brasil. Revista Brasileira de Zoologia, v. 23, p. 1175-1184, 2006.

Medeiros, P. M. Uso de produtos madeireiros para fins domésticos em uma área de Floresta Atlântica no nordeste brasileiro. Recife: Universidade Federal Rural de Pernambuco, 2010. (Thesis).

Medeiros, P. M.; Almeida, A. L. S.; Silva, T. C.; Albuquerque, U. P. Pressure indicators of wood resource use in an Atlantic Forest Area, Northeastern Brazil. Environmental Management, v. 47, p. 410-424, 2011.

Misra, M. K.; Sahu, N. C.; Rao, B. G.; Nisanka, S. K. Domestic fuel energy consumption in Indian urban ecosystem. Biomass and Bioenergy, v. 9, n. 6, p. 473-486, 1995.

Monteiro, J. M.; Albuquerque, U. P.; Lins Neto, E. M. F.; Amorim, E. L. C.; Araujo, E. L. Use patterns and knowledge of medicinal species among two rural communities in Brazil's Semi-Arid Northeastern Region. Journal of Ethnopharmacology, v. 105, p. 173-186, 2006.

Monteiro, J. M.; Lucena, R. F. P.; Alencar, N. L.; Nascimento, V. T.; Araújo, T. A. S.; Albuquerque, U.P. When intention matters: comparing three ethnobotanical data collection strategies. In: Albuquerque, U. P.; Ramos,
M. A. (Orgs.). Current topics in ethnobotany. India: Research Signpost, 2008. p. 113-124.

Moraes, A. M.; Martins, G.; Trigoso, F. B. M. O uso do fogão a lenha no semiárido piauiense: um estudo de caso. Anais do $7^{\circ}$ Congresso Internacional Sobre Geração Distribuída e Energia no Meio Rural (AGRENER), São Paulo, 2008. Available from: $<$ http://www.nipeunicamp.org.br/agrener/anais/ 2008/Artigos/80.pdf $>$. Accessed in: Nov. 11, 2015.

Mutchnick, P. A.; McCarthy, B. C. An ethnobotanical analysis of the tree species common to the subtropical moist forest of the Peten, Guatemala. Economic Botany, v. 51, n. 2, p. 158-183, 1997.

Nascimento, V. T.; Sousa, L. G.; Alves, A. G. C.; Araújo, E. L.; Albuquerque, U. P. Rural fences in agricultural landscapes and their conservation role in an area of Caatinga (dryland vegetation) in Northeast Brazil. Environment, Development and Sustainability, v. 11, p. 1005-1029, 2009.

Nagothu, U. S. Fuelwood and fodder extraction and deforestation: maistream views India discussed on the basis of data from the semiarid region of data from the Semi-Arid Region of Rajasthan. Geoforum, v. 32, n. 3, p. 319332, 2001.

Nimer, E. Climatologia do Brasil. Rio de Janeiro: IBGE, 1979.

Oliveira, J. A.; Gonçalves, P. R.; Bonvicino, C. R. Mamíferos da Caatinga. In: Leal, R.L.; Tabarelli, M.; Silva, J. M. C. (Eds.). Ecologia e conservação da Caatinga. Recife: Editora da UFPE, 2003. p. 275-333.

Oliveira, R. L. C.; Lins Neto, E. M. F.; Araújo, E. L.; Albuquerque, U.P. Conservation priorities and population structure of woody medicinal plants in area of Caatinga vegetation (Pernambuco State, NE Brazil). Environmental Monitoring and Assessment, v. 132, p. 189206, 2007.

Posey, D. A.; Overal, W. L. (Orgs.). Ethnobiology: implications and aplications. Proceedings of the First International Congress of Ethnobiology. Belém: SCT/CNPq/Museu Paraense Emílio Goeldi, 1990. v. 1 and v. 2.

Prado, D. E. As Caatingas da América do Sul. In: Leal, I. R.; Tabarelli, M.; Silva, J. M. C. (Eds.). Ecologia e conservação da caatinga. Recife: Ed. Universitária da UFPE, 2003. p. 373.

Pérez-Negrón, E.; Casas, A. Use extraction rates and spatial availability of plant resources in the 
Tehuacan-Cuicatlán Valley, Mexico: the case of Santiago Quiotepec Oaxaca. Journal of Arid Environments, v. 70, p. 356-379, 2007.

Pegado, C. M. A.; Andrade, L. A.; Féliz, L. P.; Pereira, I. M. Efeitos da invasão biológica de algaroba - Prosopis juliflora (Sw.) DC. sobre a composição e a estrutura do estrato arbustivoarbóreo da Caatinga no Município de Monteiro, PB, Brasil. Acta Botânica Brasílica, v. 20, n. 4, p. 887-898, 2006.

Ramos, M. A.; Medeiros, P. M.; Almeida, A. L. S.; Feliciano, A. L. P.; Albuquerque, U. P. Use and knowledge of fuelwood in an area of Caatinga vegetation in NE Brazil. Biomass e Bioenergy, v. 32, p. 510-517, 2008a.

Ramos, M. A.; Medeiros, P. M.; Almeida, A. L. S.; Feliciano, A. L. P.; Albuquerque, U. P. Can wood quality justify local preferences for firewood in an area of Caatinga (dryland) vegetation. Biomass e Bioenergy, v. 32, p. 503509, 2008b.

Ramos, M. A.; Albuquerque, U.P. The domestic use of firewood in rural communities of the Caatinga: how seasonality interferes with patterns of firewood collection. Biomass e Bioenergy, v. 39, p. 147-158, 2012.

Reyes-Garcia, V.; Vadez, V.; Huanca, T.; Leonard, W.; Wilkie, E. D. Knowledge and consumption of wild plants: a comparative study in two Tsimane Villages in the Bolivian Amazon. Ethnobotany Research and Applications, v. 3, p. 201-207, 2005.

Rodrigues, L. A.; Carvalho, D. A.; Gomes, L. J.; Botrel, R. T. Espécies vegetais nativas usadas pela população local em luminárias, MG. Boletim Agropecuário - Universidade Federal de Lavras/MG, v. 52, p. 1-34, 2002.

Sá, I. M. M.; Marangon, L. C.; Hanazaki, N.; Albuquerque, U.P. Use and knowledge of fuelwood in three rural caatinga (dryland) communities in NE Brazil. Environment, Development and Sustainability, v. 11, p. 833852, 2009.

Sampaio, E. V. S. B.; Gamarra-Rojas, C. F. L. Uso das plantas em Pernambuco. In: Tabarelli, M.; Silva, J. M. C. (Orgs.). Diagnóstico da biodiversidade de Pernambuco. Recife: Secretaria de Ciências, Tecnologia e Meio Ambiente, Editora Massangana, 2002. v. 2. p. 633-660.

Shankar, U.; Hedge, R.; Bawa, S. Extraction of non-timber forest products in the forest of Biligiri Rangan Hills, India. Fuelwood pressure and management options. Economic Botany, v. 52, p. 320-336, 1998.
SEMARH - Secretaria do Meio Ambiente e Recursos Hídricos. Campina Grande, 2004.

Samant, S. S.; Dhar, U.; Rawal, R. S. Assessment of fuel resource diversity and utilization patterns in Askot Wildlife Sanctuary in Kumanun Himalaia, India, for conservation and management. Environmental Conservation and Management, v. 27, n. 1, p. 5-13, 2000.

Sanga, G. A. Avaliação de impactos de tecnologias limpas e substituição de combustíveis para cocção em residências urbanas na Tanzânia. Campinas: Universidade Estadual de Campinas, Faculdade de Engenharia Mecânica, 2004. (Graduate thesis).

Severo, T. E.; Lima, J. R. F.; Noia, N. P.; Silva, M. J. B. A. As cadeias reativas verdes. 1. ed. Campina Grande: Gráfica Adilson, 2009.

Silva, A. M. Uso e conservação de um remanescente de caatinga arbórea no Município de Cajazeiras-PB. Recife: Universidade Federal de Pernambuco, 2002. (Graduate thesis).

Silva, N.; Lucena, R. F. P.; Farias, J. R.; Lima, G. D. S.; Carvalho, T. K. N.; Sousa Júnior, S. P.; Alves, C. A. B. Conhecimento e uso da vegetação nativa da Caatinga em uma Comunidade Rural da Paraíba, Nordeste do Brasil. Boletim do Museu de Biologia Mello Leitão, v. 34, p. 5-37, 2014.

Sousa, R. F.; Barbosa, M. P., Morais Neto, J. M.; Fernandes, M. F. Estudo do processo da desertificação em Cabaceiras-PB. Revista de Engenharia Ambiental, v. 4, n. 1, p. 89-102, 2007.

Sousa, R. F.; Gomes, D. S.; Leite, A. P.; Santos, S. S.; Alves, C. A. B.; Lucena, R. F. P. Estudo etnobotânico de Myracrodruon urundeuva Allemão em uma comunidade rural na Microrregião de Itaporanga, Paraíba, Brasil. Revista Brasileira de Biologia e Farmácia Biofar, v. 7, n. 1, p. 72-83, 2012.

Shanley, P.; Rosa, N. A. Eroding Knowledge: An ethnobotanical inventory in Eastern Amazonia's logging frontier. Economy Botany, v. 58, n. 2, p. 135-160, 2004.

Stagegaard, J.; Sorensen, M.; Kvist, L. P. Estimations of the importance of plant resources extracted by inhabitants of the Peruvian Amazon flood plains. Perspectives in Plant Ecology, Evolution and Systematics, v. 5, p. 103-122, 2002.

Tabuti, J. R. S.; Dhillion, S. S.; Lyea, K. A. Firewood use in Bulamogi Country, Uganda: species selection, harvesting, and consumption 
patterns. Biomass and Bioenergy, v. 25, p. 581-596, 2003.

Ventura-Aquino, Y.; Rendón, B.; Rebollar S.; Hernández, G. Use and conservation of forest resources in the Municipality of San Agustin Loxicha, Sierra Madre del Sur, Oaxaca, Mexico. Agroforesty System, v. 73, p. 167-180, 2008.

WLPGA - World Liquefied Petrolium Gas Association, 2004. Available from: $<$ http://www.lpgas.com $>$. Accessed in: jan. 21, 2015 .

License information: This is an open-access article distributed under the terms of the Creative Commons Attribution License, which permits unrestricted use, distribution, and reproduction in any medium, provided the original work is properly cited. 